\title{
Toxicity of Wheat Flour Proteins and Protein- Derived Peptides for In Vitro Developing Intestine from Rat Fetus
}

\author{
G. DE RITIS, P. OCCORSIO, S. AURICCHIO, F. GRAMENZI, G. MORISI, AND V. SILANO \\ Clinica Pediatrica, II Facoltà di Medicina e Chirurgia, Naples, Program of Preventive Medicine (Project of perinatal \\ medicine), Consiglio Nazionale delle Ricerche, Laboratorio di Tossicologia, and Laboratorio di Tecnologie \\ Biomediche, Istituto Superiore di Sanita, Rome, Italy
}

THIS PAPER IS DEDICATED BY THE AUTHORS TO PROFESSOR ANDREAS PRADER ON THE OCCASION OF HIS 60TH BIRTHDAY.

\begin{abstract}
Summary
A peptic-tryptic-cotazym (PTC) digest of a crude wheat gliadin preparation was obtained under experimental conditions simulating in vivo protein digestion and then fractionated into 10 peaks by ion-exchange chromatography. PTC-gliadin digest and one of its subfractions (coded as fraction 9 according to its elution pattern) were very active in inhibiting in vitro development and morphogenesis of small intestine from 17- and 18-day-old rat fetuses, whereas they were harmless for the culture of jejunum from 21-day-old fetuses. PTC-digest also induced extensive tissue degeneration and necrosis of in vitro cultured small intestinal mucosa from patients with active celiac disease (gluten-induced entheropathy), but did not cause any detectable effect on histologically normal human small intestinal mucosa. Some wheat albumin and gliadin fractions were also tested on in vitro developing small intestine from 17-day-old rat fetus. Among all the tested protein fractions, only one gliadin fraction (coded as $\alpha_{10}$-gliadin from its gel electrophoretic mobility) exhibited a toxic effect; morphologic alterations induced by $\alpha_{10}$-gliadin were similar to those induced by PTC-digest and fraction 9.
\end{abstract}

\section{Speculation}

Peptides obtained from wheat gliadins under in vitro conditions simulating protein digestion by humans as well as whole wheat gliadin are very active in damaging in vitro developing jejunum from 17- and 18-day-old rat fetuses, but have no toxic effect on the culture of jejunum from 21-day-old rat fetus. The transient character of such an effect is suggestive of a protective mechanism against the toxic protein components from wheat, associated with the age-dependent maturation of rat intestinal mucosa. It is speculated that also human normal intestine develops with maturation similar specific detoxifying mechanisms and that wheat gliadin and gliadin-derived peptides might exert a toxic action when human intestinal mucosa is not yet fully mature (i.e., during early extrauterine life) or when adult human mucosa regresses towards immature steps of development (i.e., in intestinal diseases with mucosal atrophy).

Although wheat and wheat products have been for thousands of years the major food items in the diet of man, proteins and protein-derived peptides from wheat kernel endosperm can induce adverse effects in man under particular circumstances. A typical relevant condition in this respect is celiac disease (gluten-induced entheropathy) (24). The role of $\alpha$-gliadin as a toxic factor in the pathogenesis of coeliac disease was first suggested by Hekkens $e t$ al. $(15,16)$ and confirmed by Kendall et al. $(27)$. Recently, Kasarda et al. (25) have suggested that wheat cultivars lacking the $6 \mathrm{~A}$ chromosome and most of the A-gliadin proteins may not be toxic at all in coeliac disease. However, other authors (21) tend to believe that other gliadin components, besides the $\alpha$-ones, may be involved in the pathogenesis of celiac disease.

Not only whole gliadin proteins, but also peptides deriving from proteolytic digestion of wheat gliadins are toxic in celiac disease. A peptic-tryptic digest of a crude gliadin preparation was found to be toxic for cultured small intestinal mucosa from patients with active celiac disease $(10,11,22,23)$, but not for that from normal individuals and individuals with treated celiac disease: immune response may be involved in such mechanism $(12,26)$.

However, the specificity of the effect of gliadin peptides on the in vitro cultured small intestinal mucosa from patients with active celiac disease has been questioned because adverse effects are also induced by peptic-tryptic digest of casein and human albumin (22).

Cornell and Townley (8) have reported the ion-exchange fractionation of the peptic-tryptic-cotazym digest of a crude gliadin preparation into 10 major peptidic fractions. The fraction eluted with $0.02 \mathrm{M}$ phosphate buffer (coded as fraction 9) was shown to be extremely toxic for cultured mucosa of patients with active celiac disease (38), as well as for intestinal cells, and for other various human cell types cultured in vitro $(13,17)$. Such cytotoxicity was inhibited by normal human and calf serum.

There are indications that wheat gluten or gluten fractions might have a harmful role in other types of small intestinal diseases. Bayless and Swanson (2) reported that patients with tropical sprue responded to a gluten-free diet with a decreased steatorrhea and with an improvement in the jejunal lesions. Hedberg et al. (14) described a postgastrectomy steatorrhea that was improved by a gluten-free diet. Levine et al. (28) found that in some subjects convalescing from Laennec's cirrhosis, tuberculosis, or viral hepatitis a significant increase in fecal fat excretion resulted upon addition of $1-0-150 \mathrm{~g}$ gluten daily to the diet; no effect was observed with normal individuals. Rudman et al.(36) demonstrated that patients with regional enteritis suffer from gastrointestinal bleeding, increased steatorrhea, fever, diarrhea, and abdominal discomfort due to inclusion of gluten in the diet. There is no evidence that the components of gluten that played a role in aggravating intestinal lesions in these diseases are the same that cause the symptoms of celiac disease (36). Temporary gluten intolerance (31) as well as gluten sensitive diarrhea without evidence of celiac disease (7) have also been described.

The detection and characterization of wheat components that may be toxic for man under some conditions is very difficult because of the lack of suitable in vitro methods for toxicity testing. This applies to compounds responsible for celiac disease as well as to those involved in other intolerances to wheat proteins. Because recently, it has been shown (9) that differentiation and 
maturation of small intestinal mucosa from rat fetus may take place in vitro in a way comparable to what happens in vivo, the authors wanted to test whether such a tissue provides an in vitro system suitable for the study of wheat toxic proteins and peptides. Therefore, this paper deals with the effect of wheat proteins and peptide fractions on in vitro development of rat fetal intestine.

\section{MATERIALS AND METHODS}

\section{PURIFIED GLIADIN AND ALBUMIN FRACTIONS}

$\alpha_{10}$-Gliadin purified according to Huebner and Rothfus (18), was generously supplied by Dr. F. R. Huebner. A-gliadin, purified according to Bernardin et al. (3), was a gift from Dr. D. D. Kasarda. Albumin fractions of molecular weights 12,000, 24,000, and 60,000 , active in inhibiting $\alpha$-amylases from different origins (6), were prepared by submitting a crude albumin preparation from wheat flour to gel filtration on Sephadex G-100 according to Petrucci et al. (33).

\section{PREPARATION OF CRUDE GLIADIN}

A crude gliadin preparation was obtained by suspending $1 \mathrm{~kg}$ of commercial wheat gluten (Buitoni, Perugia, Italy) in 10 liters of ethanol-water $(70: 30, \mathrm{v} / \mathrm{v})$ solution. After $1 \mathrm{hr}$ magnetic stirring at room temperature, the suspension was centrifuged at $15,000 \mathrm{X} g$ and the clear supernatant was added with 3 volumes of $99 \%$ ethanol. The precipitated gliadin was collected by centrifuging at $15,000 \times \mathrm{g}$ and then freeze-dried. This procedure is basically that of Jones and coworkers $(19,20)$.

\section{PURIFICATION OF COMMERCIAL PEPSIN, TRYPSIN AND COTAZYM PREPARATIONS}

Pepsin (three times crystallized) and trypsin (twice crystallized) were supplied by Fluka AG (Buchs, Switzerland); cotazym, an extract of hog pancreas, was obtained from Organon Inc. (New Jersey, USA). About $2 \mathrm{~g}$ of trypsin or cotazym were dissolved in $50 \mathrm{ml}$ of $0.1 \mathrm{M}$ ammonium acetate $(\mathrm{pH} \mathrm{7.8)}$ ) and centrifuged at $40,000 \mathrm{Xg}$ for $20 \mathrm{~min}$. Then, the clear supernatant was applied on a column $(140 \times 6 \mathrm{~cm})$ of Sephadex G-100 (Pharmacia, Uppsala, Sweden) and eluted with the same buffer. Pepsin was dissolved in $0.1 \mathrm{M}$ acetic acid (pH 3.0) and loaded on an equal-size Sephadex G-100 column equilibrated with the acetic acid solution. The eluate flow rate was in all the cases $60 \mathrm{ml} / \mathrm{hr}$. The absorbance of the eluate at $280 \mathrm{~nm}$ was monitored (Photochrom flow analyzer,
Rastelli, Italy) and recorded (Kompensograph, Siemens, Germany) continuously. Fractions $(20 \mathrm{ml})$ were collected, pooled as indicated by the bar in Figure 1, and freeze-dried.

The gel column was calibrated with proteins of known molecular wt to determine apparent molecular wt of protein and peptide fractions according to the method of Andrews (1). Reference proteins were: cytochrome c (MW 12500$)$ and chymotrypsinogen (MW 25 700) from Sigma Chemical Company (St. Louis, USA), and bovine serum albumin from Armour Pharmaceutical Company (Chicago, USA). Blue Dextran was from Pharmacia (Uppsala, Sweden).

When submitted to gel filtration on Sephadex G-100, commercial preparations of crystallized pepsin and trypsin showed, in addition to a main peak, a second large peak with lower apparent molecular wt (Fig. 1) probably consisting of self-proteolytic products of the two digestive enzymes. Under identical experimental conditions, cotazym, a crude extract from hog pancreas, showed two very large peaks with low molecular wt and two minor peaks with molecular wt higher than that of cytochrome $c$.

To prevent large contamination of the gliadin digest by the low molecular wt components of pepsin, trypsin, and cotazym, fractions corresponding to peaks with retention volumes higher than 2.5 (indicated in Fig. 1 by the bar) were pooled and used for gliadin digestion.

\section{PREPARATION OF PEPTIC-TRYPTIC-COTAZYM DIGEST OF CRUDE GLIADIN}

PTC gliadin digest was prepared following the three-step procedure of Bronstein et al. (4). One hundred $\mathrm{g}$ of gliadin pool was digested in 1 liter of $0.2 \mathrm{~N} \mathrm{HCl}(\mathrm{pH} 1.8)$ with $2 \mathrm{~g}$ of purified pepsin at $37^{\circ} \mathrm{C}$ for $2 \mathrm{hr}$. The resultant peptic digest was further digested by addition of $2 \mathrm{~g}$ of purified trypsin after $\mathrm{pH}$ adjustement to 8.0 with $2 \mathrm{~N} \mathrm{NaOH}$. The reaction mixture was vigorously stirred at $37^{\circ} \mathrm{C}$ for $4 \mathrm{hr}$ at $\mathrm{pH} 8.0$. Then, the peptic-tryptic digest was treated with $2 \mathrm{~g}$ of purified cotazym and mechanically stirred for $2 \mathrm{hr}$ at $\mathrm{pH}$ 8.0. During the entire digestion procedure, the $\mathrm{pH}$ was checked periodically and, when needed, adjusted with $\mathrm{HCl}$ or $\mathrm{NaOH}$.

Ten $\mathrm{ml}$ of the supernatant of each digestion step-i.e., peptic, peptic-tryptic, and peptic-tryptic-cotazym were submitted to gel filtration as described previously to follow changes in the apparent molecular wt pattern of the digest.

As shown by the large changes observed among the molecular wt patterns of peptic-tryptic, and peptic-tryptic-cotazym digests (Fig. 2), the purified enzymes were highly effective in hydrolyzing

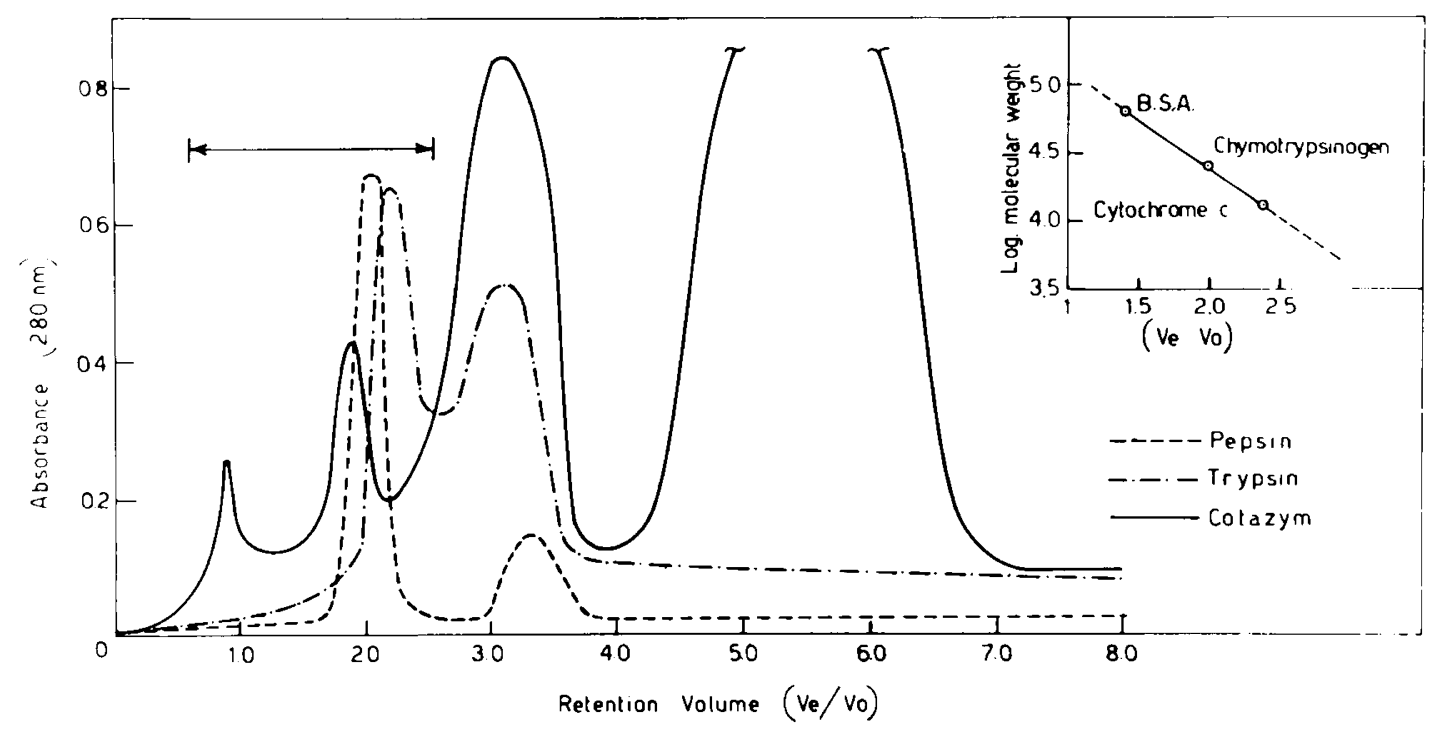

Fig. 1. Purification of commercial pepsin, trypsin, and cotazym by gel filtration. About $2 \mathrm{~g}$ of enzyme were loaded on a (140 $\times 6 \mathrm{~cm})$ column of Sephadex G-100; the eluent was $0.1 \mathrm{M}$ ammonium acetate for trypsin and cotazym and 0.1 acetic acid for pepsin; fractions corresponding to peaks with retention volumes higher than 2.5 , indicated by the bar, were pooled and freeze-dried. 


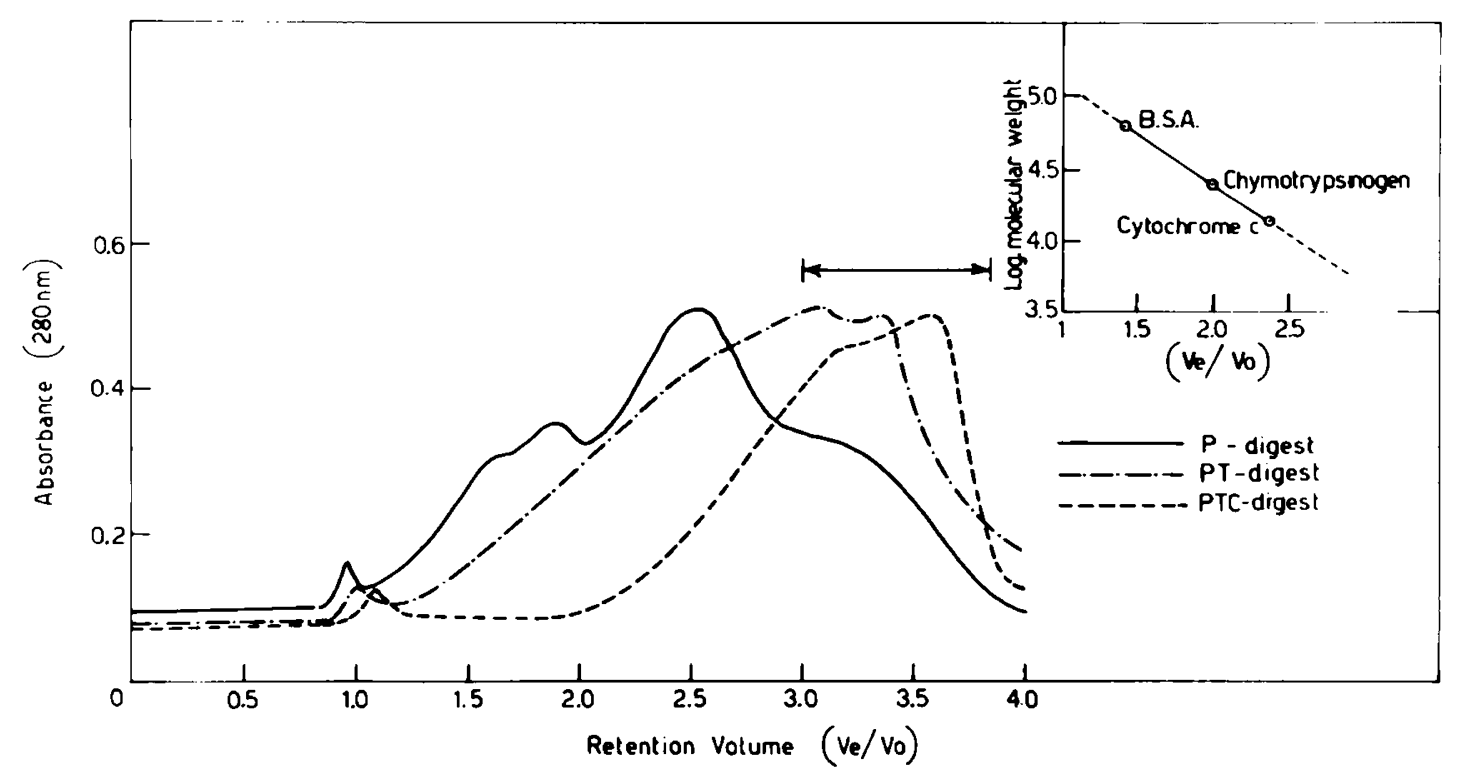

Fig. 2. Fractionation of peptic digest, peptic-tryptic digest, and peptic-tryptic-cotazym digest of wheat gliadin by filtration. About $100 \mathrm{~g}$ of gliadin were digested in 1 liter of $0.2 \mathrm{~N} \mathrm{HCl}, \mathrm{pH} 1.8$, with $2 \mathrm{~g}$ of purified pepsin at $37^{\circ} \mathrm{C}$ for $2 \mathrm{hr}$. The resultant digest was further digested for $4 \mathrm{hr}$ by addition of $2 \mathrm{~g}$ of purified trypsin after $\mathrm{pH}$ adjustement to 8.0 with $2 \mathrm{~N} \mathrm{NaOH}$. Then the peptic-tryptic digest was treated with $2 \mathrm{~g}$ of purified cotazym and mechanically stirred for $2 \mathrm{hr}$ at $\mathrm{pH} 8.0$. Then $\mathrm{ml}$ were loaded on a $(140 \times 6 \mathrm{~cm})$ column of Sephadex G-100 and eluted with $0.1 \mathrm{M}$ ammonium acetate.

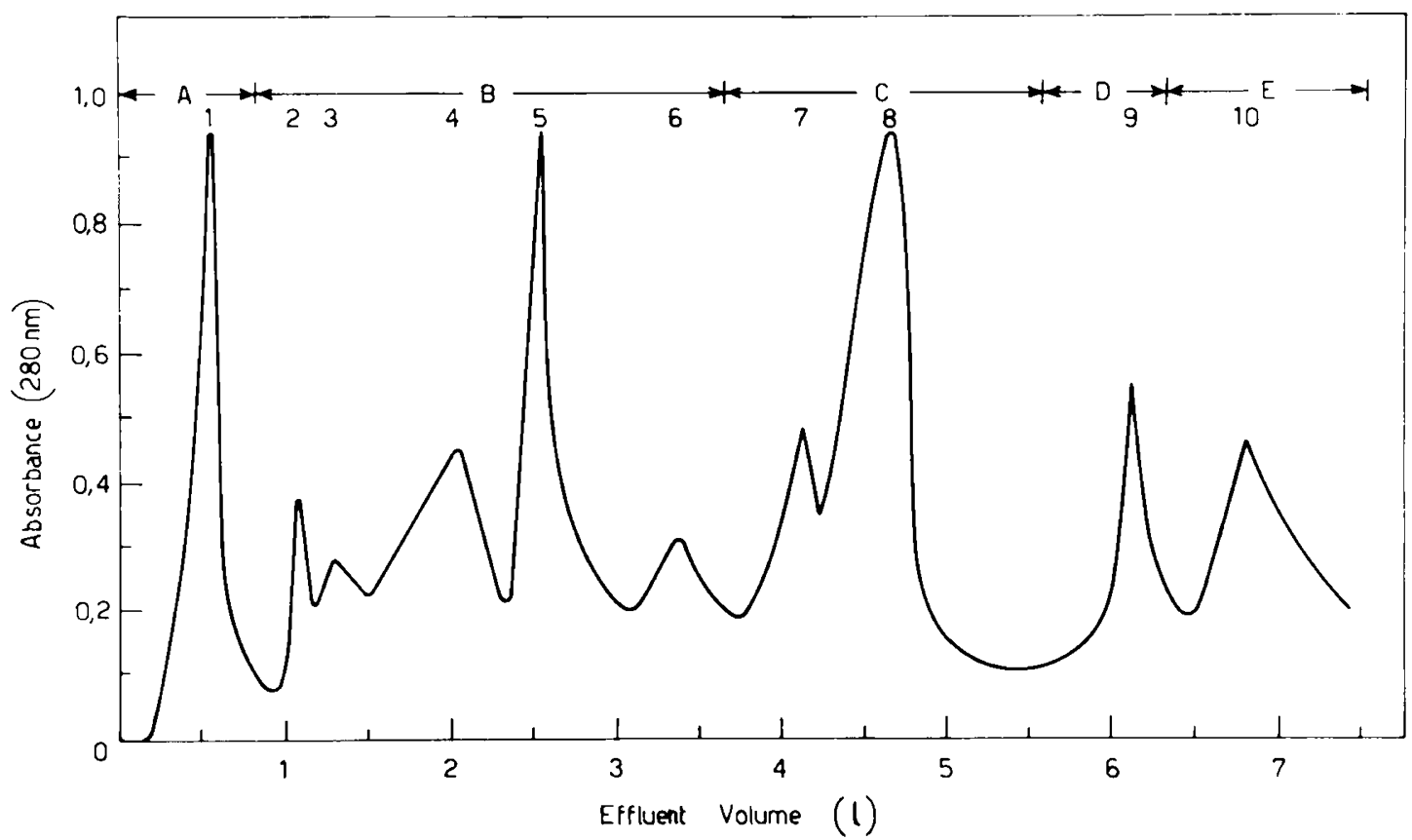

Fig. 3. Fractionation of peptic-tryptic-digest of wheat gliadin by ion-exchange chromatography. About $5 \mathrm{~g}$ of PTC-gliadin digest were dissolved in $80 \mathrm{ml}$ of $0.005 \mathrm{M}$ phosphate buffer, $\mathrm{pH} 3.1$, and loaded on a $(60 \times 4.5 \mathrm{~cm})$ column of Sephadex SP-G25. Elution buffers were: $A$ 0.005 $\mathrm{M}$ phosphate buffer, $\mathrm{pH} 3.1 ; B 0.02 \mathrm{M}$ phosphate buffer, $\mathrm{pH} 5.5 ; C$ linear $\mathrm{pH}$ gradient to $\mathrm{pH} 6.3 ; D 0.02 \mathrm{M}$ phosphate buffer, $\mathrm{pH} 8.0 ; E 0.02 \mathrm{M}$ phosphate buffer, $\mathrm{pH}$ 8.0 , containing $0.25 \mathrm{M} \mathrm{NaCl}$.

the gliadin pool extracted from commercial gluten with $70 \%$ ethanol and purified by adding ethanol up to $92.5 \%$.

At the end of the whole digestion procedure, the digest was submitted to gel filtration and the peptide fractions eluted after cytochrome $\mathrm{c}$ were collected and freeze-dried. This enzyme-free low-molecular-wt peptide pool has been coded as PTC gliadin digest. Moreover, a PTC bovine serum albumin digest to be used as control was prepared under identical experimental conditions.

\section{FRACTIONATION OF PTC GLIADIN DIGEST}

Fractionation of PTC gliadin digest was accomplished as described by Cornell and Townley ( 8 ) by ionic-exchange chroma- tography on a column $(60 \times 4.5 \mathrm{~cm})$ of Sephadex SP G-25 (Pharmacia, Uppsala). About $5 \mathrm{~g}$ of PTC gliadin digest were dissolved in $80 \mathrm{ml}$ of a $0.005 \mathrm{M}$ phosphate buffer ( $\mathrm{pH} \mathrm{3.1)}$ and loaded on the column. Elution buffers and procedures are reported in Figure 3. The eluate absorbance was monitored and recorded as above described.

Ten peaks were obtained from this fraction with elution programme of Cornell and Townley (8) which included increasing $\mathrm{pH}$ and ionic strength (Fig. 3). The elution pattern of PTC gliadin digest, although not identical, was closely related to that obtained under comparable conditions by Cornell and Townley (8). Moreover, fraction 9 , when tested with the chromatographic technique 
of Spackman et al. (37) as reported by Petrucci et al. (33), showed an amino acid composition closely related to that of the corresponding fraction 9 described by Cornell and Townley (8).

\section{IN VITRO CULTURE OF FETAL RAT JEJUNUM}

Timed-pregnant Wistar rats were anesthetized with ether and 17-, 18- and 21-day fetuses were removed at laparotomy. Fetal jejunum segments were isolated and cultured in vitro for 24,48 , and $72 \mathrm{hr}$ in a serum-free medium, according to the method described by de Ritis et al. (9). Jejunal segments from the same fetus were cultured in the absence and in the presence of tested proteins and peptides from wheat. When necessary, $\mathrm{pH}$ of incubation medium was adjusted to 7.4 by adding sterile $\mathrm{NaOH}$. After $24 \mathrm{hr}$ culture, the incubation medium was substituted with fresh medium. Baseline and cultured jejunal segments were fixed by immersion for $60 \mathrm{~min}$ in chilled $1 \%$ osmium tetroxide buffered at pH 7.4 in $0.1 \mathrm{M}$ phosphate buffer. Tissues were then rapidly dehydrated in graded concentrations of ethanol and embedded in epoxy resin using Luft's method (29). The embedded tissues were then carefully oriented and mounted on aluminum rods for sectioning. Sections of the block were then cut $1 \mu \mathrm{m}$ thick with a Sorvall MT-2 microtome, mounted on glass slides, and stained with Richardson's stain (35). Morphologic differentiation of the fetal rat jejunum was followed by light microscopy examination.

\section{IN VITRO CULTURE OF HUMAN SMALL INTESTINAL MUCOSA}

Intestinal biopsies were obtained from two children and three adults who underwent this procedure to clarify the cause of chronic unspecific diarrhea. The intestinal mucosa in all these cases was found to be histologically normal and the final diagnosis was irritable colon. Intestinal biopsies were also obtained from four children affected by active coeliac disease with subtotal mucosal atrophy. The tissues were cultured for $48 \mathrm{hr}$ in a serum containing medium, without or with added wheat peptide fractions, according to the method of Browning and Trier (5) as modified by Jos et al. (23). The medium was changed after $24 \mathrm{hr}$ culture. Biopsy specimens just after their excision and after $48 \mathrm{hr}$ culture were fixed in $10 \%$ formol, dehydrated, embedded in paraffin, and serially sectioned.

\section{RESULTS}

\section{IN VITRO CULTURE OF HUMAN AND RAT INTESTINE}

As indicated by light microscopy examination, jejunal segments from 34 17-day-old rat fetuses did not show before in virro culture any villus and only undifferentiated cuboidal stratified epithelia lining the jejunum were present (Table 1 and Fig. 4 a). Only in one case, few very rudimentary villi were observed. Moreover, in all the cases, no goblet cells could be detected at this stage of tissue development. After $48 \mathrm{hr}$ in vitro culture, there were clear morphologic evidences of tissue maturation. Well differentiated villi were present in cultured jejunal segments from as many as 30 fetuses and rudimentary villi were observed in the cultured tissues from the ramaining four fetuses (Table 1, Fig. 4 b). The epithelial lining consisted exclusively of simple columnar epithelium in almost all the cultured jejunal segments and in only two fetuses the monostratified epithelium consisted of a mixture of columnar and cuboidal cells. Goblet cells were identified in 26 cases. Patchy slight degenerative changes characterized by a decreased cytoplasmic staining, nuclear pycnosis, and large lysosome-like inclusions were observed in a few cultured jejunal segments from six fetuses. When jejunal segments from 27 fetuses were cultured for $24 \mathrm{hr}$ instead of $48 \mathrm{hr}$, a significantly less developed mucosal architecture was observed, whereas morphologic appearence of tissue segments cultured for $72 \mathrm{hr}$, apart from a more frequent occurence of slight degenerative changes, did not significantly differ from that observed after $48 \mathrm{hr}$ culture.

A large percent (about 50\%) of jejunal segments from 18-dayold rat fetuses showed before in vitro culture well developed villi and monostratified epithelium. After the in vitro culture, morphology of these jejunal segments was similar to that of the segments obtained from 17-day-old rat fetuses. These findings confirm previous results by de Ritis et al. (9) and support the standpoint that differentiation and maturation of small intestinal mucosa from rat fetuses takes place in vitro in a way comparable to what happens in vivo. The authors have also been able to culture for $48 \mathrm{hr}$ without any morphologic evidence of tissue sufference small intestinal mucosa from humans.

\section{EFFECT OF PEPTIC-TRYPTIC-COTAZYM DIGEST OF WHEAT GLIADIN}

The peptic-tryptic-cotazym digest (PTC digest) of gliadin was prepared by submitting a crude gliadin preparation from wheat gluten to consecutive in vitro digestion with purified pepsin, trypsin, and cotazym, under conditions simulating the in vivo protein digestion (see experimental section). The addition of $0.5 \mathrm{mg}$ peptides of the PTC gliadin digest to each $\mathrm{ml}$ of tissue incubation medium slowed down in vitro development of fetal rat intestine and increased occurrence and severity especially at the mesenchyme level of the degenerative changes sporadically observed in the control tissue (Table 1, Fig. $4 \mathrm{c}$ ). After $48 \mathrm{hr}$ culture, well differentiated villi were present in jejunal segments from only two fetuses, whereas villi were rudimentary in 11 cases and absent in five cases. Moreover, in the presence of the PTC gliadin digest the epithelium was monostratified in all the cases, but it was totally or partially cuboidal. Goblet cells were present only in jejunal segments from four fetuses. Slight degenerative changes similar to those mentioned previously were observed in cultured segments from 14 fetuses. In four cases, the degenerative changes were severe and some necrotic areas involving both epithelial and

Table 1. Morphologic features of maturation of rat fetal jejunum cultured in vitro in the absence or in the presence of gliadin peptides

\begin{tabular}{|c|c|c|c|c|c|c|c|c|c|c|}
\hline \multirow[b]{3}{*}{ Sample } & \multicolumn{3}{|c|}{ Villi } & \multicolumn{4}{|c|}{ Epithelium } & \multirow{3}{*}{$\begin{array}{c}\begin{array}{c}\text { Goblet } \\
\text { cells }\end{array} \\
\text { Present }\end{array}$} & \multicolumn{2}{|c|}{$\begin{array}{l}\text { Degenerative } \\
\text { changes }\end{array}$} \\
\hline & \multirow[b]{2}{*}{ Absent } & \multirow[b]{2}{*}{ Rudimentary } & \multirow[b]{2}{*}{ Present } & \multirow[b]{2}{*}{ Stratified } & \multicolumn{3}{|c|}{ Monostratified } & & \multirow[b]{2}{*}{ \pm} & \multirow[b]{2}{*}{++} \\
\hline & & & & & Cuboidal & Columnar & Mixed & & & \\
\hline Uncultured 17-day fetuses $(34)^{2}$ & 33 & 1 & & 34 & & & & 0 & 0 & $\overline{0}$ \\
\hline $\begin{array}{l}\text { After } 48 \mathrm{hr} \text { culture without gliadin } \\
\text { proteins or peptides }(34)^{2}\end{array}$ & & 4 & 30 & & & 32 & 2 & 26 & 6 & 0 \\
\hline $\begin{array}{l}\text { After } 48 \mathrm{hr} \text { culture with PTC-glia- } \\
\text { din digest }(0.5 \mathrm{mg} / \mathrm{ml})(18)^{2}\end{array}$ & 5 & 11 & 2 & & 10 & 2 & 6 & 4 & 14 & 4 \\
\hline $\begin{array}{l}\text { After } 48 \mathrm{hr} \text { culture with fraction } 9 \\
\text { from PTC-gliadin digest }(0.1 \mathrm{mg} / \\
\mathrm{ml})(16)^{2}\end{array}$ & 12 & 4 & & & 13 & 0 & 3 & 1 & & 16 \\
\hline
\end{tabular}

' \pm indicates slight degenerative changes; ++ indicates large necrotic areas.

${ }^{2}$ Number of fetuses examined or of fetal jejunums cultured. 

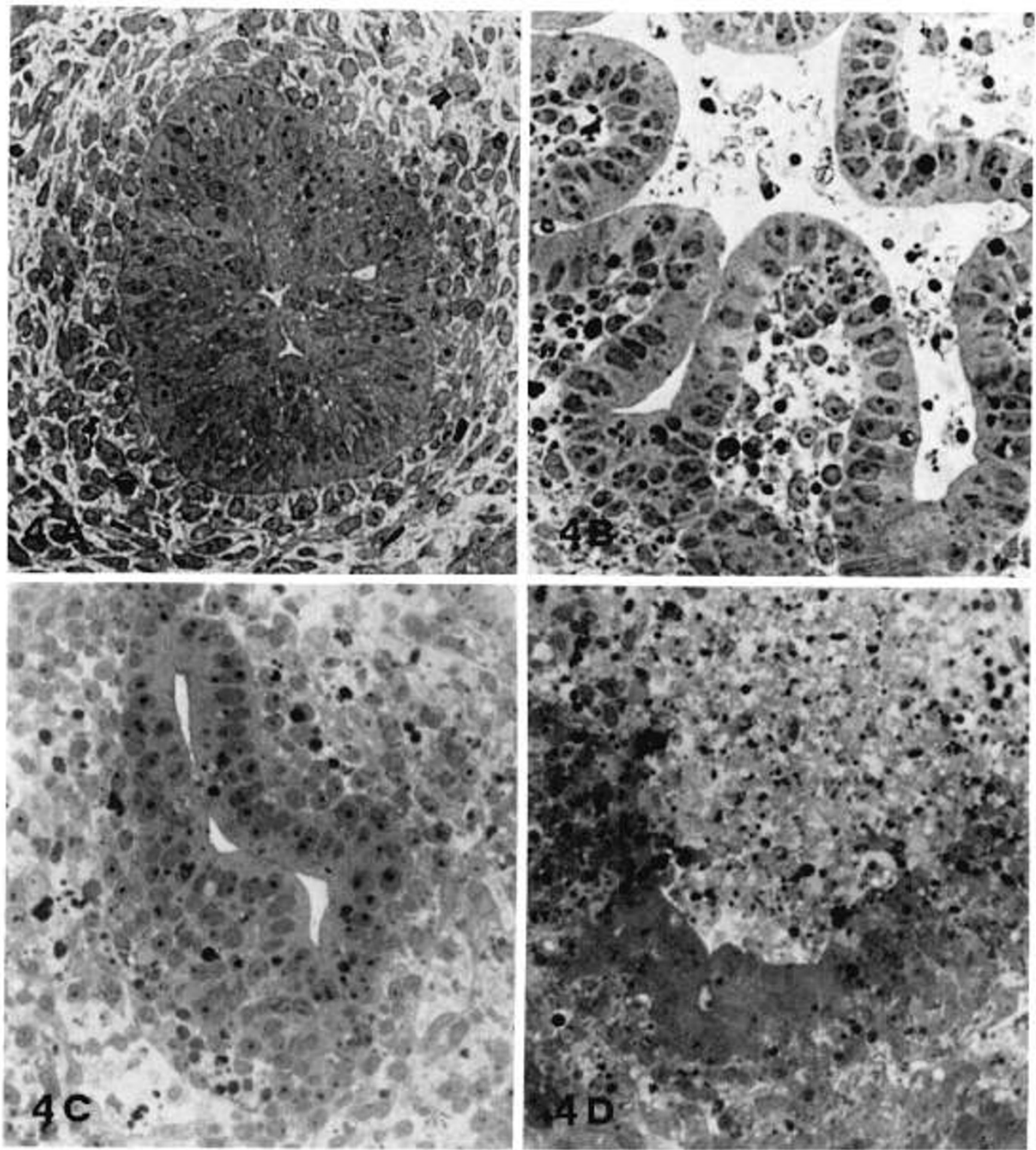

Fig. 4. Effect of peptic-tryptic-cotazym digest of wheat gliadin on in vitro development and morphogenesis of jejunum from 17-day-old rat fetus. $A$ Jejunal mucosa before culture showing no villi and an epithelium consisting of stratified undifferentiated cells. $B$ Jejunal mucosa after $48 \mathrm{hr}$ culture showing well developed villi and an epithelium consisting of a single layer of columnar cells more mature than those in the uncultured jejunum. $C$ Jejunal mucosa after $48 \mathrm{hr}$ culture in the presence of the PTC gliadin digest $(0.5 \mathrm{mg} / \mathrm{ml})$. Only rudimentary villi are present. The epithelium consists of immature single cuboidal and columnar epithelium cells. No goblet cells can be identified. Large lysosomelike inclusions are present. $D$ Jejunal mucosa after $48 \mathrm{hr}$ culture in the presence of fraction 9 from PTC-gliadin digest $(0.1 \mathrm{mg} / \mathrm{ml})$. Extensive degenerative changes and some necrotic areas are evident. Epithelial surface is often interrupted and epithelial cells show severe morphological alterations. Richardson's stain $(\times 310)$.

mesenchymal cells were present together with a large amount of necrotic material in the lumen. No change in the number of cell mitotic events was observed in the presence of the PTC gliadin digest. The in vitro effect of the PTC gliadin digest on rat fetal jejunum differentiation and maturation was observed also after only $24 \mathrm{hr}$ of culture as well as after $72 \mathrm{hr}$ of culture. Similarly, comparable results were obtained using jejunal segments from 18day-old rat fetuses instead of those from 17-day-old ones. No one of the effects induced by the PTC gliadin digest on in vitro developing rat intestine was observed in five experiments in the presence of $0.1-0.5 \mathrm{mg} / \mathrm{ml}$ of the PTC digest of serum albumin prepared under identical experimental conditions. PTC gliadin digest at a concentration of $0.5 \mathrm{mg} / \mathrm{ml}$ did not affect in vitro cultured jejunal segments from 21-day-old rat fetuses.

When tested at a $0.5 \mathrm{mg} / \mathrm{ml}$ concentration, the PTC gliadin digest did cause no detectable effect on histologically normal small intestinal mucosa from three human adults and two children (Fig. $5 \mathrm{~b}$ ), whereas it induced extensive tissue degeneration and necrosis of small intestinal mucosa from four coeliac patients with subtotal villous atrophy (Fig. 6 b). These results are in good agreement with previous findings (22) showing that gliadin digest is toxic for altered small intestinal mucosa from patients with active celiac diseases and harmless for that from individuals normal or with treated celiac disease.

\section{EFFECT OF FRACTIONS FROM PTC GLIADIN DIGEST}

Ten fractions were obtained when PTC gliadin digest was submitted to ion exchange chromatography under the conditions reported by Cornell and Townley (8). The last four fractions (coded as fractions $7,8,9,10$ ) were tested on in vitro developing rat fetal intestine at a maximal concentration of $0.5 \mathrm{mg} / \mathrm{ml}$. 


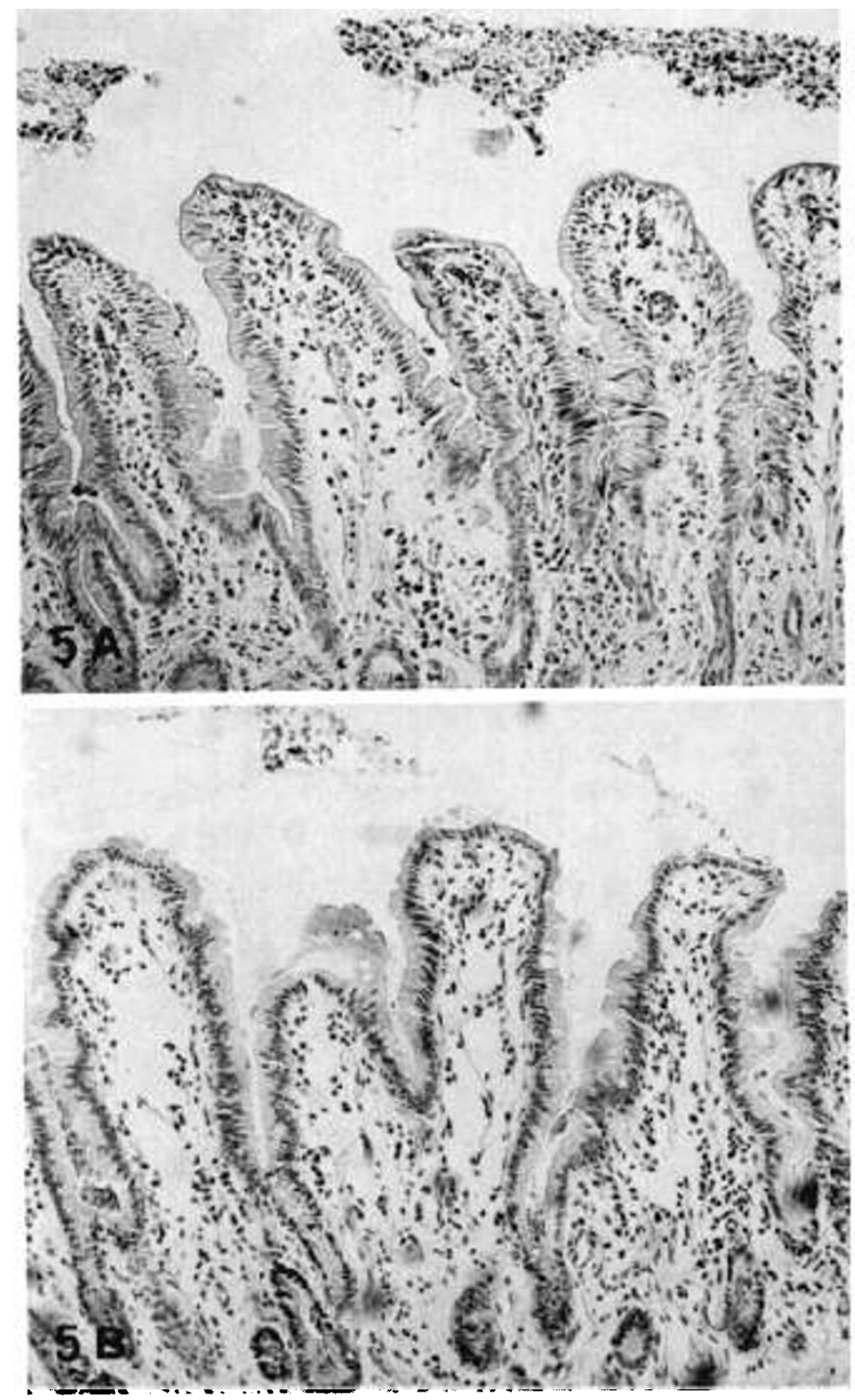

Fig. 5. Absence of effect of peptic-tryptic-cotazym digest of wheat gliadin on in virto cultured normal human jejunal biopsy. $A$ no PTC. gliadin digest; $B$ with PTC-gliadin digest $(0.5 \mathrm{mg} / \mathrm{ml})$. In both cases, after $48 \mathrm{hr}$ culture, the villous pattern and the epithelial cell morphology are well preserved. Hematoxylin-Eosin $(\times 150)$.

Fractions 7,8 , and 10 were inactive, whereas $0.1 \mathrm{mg}$ peptides of fraction 9 per $\mathrm{ml}$ of culture medium strongly affected morphology of the fetal tissue. In the presence of fraction 9, villi were absent or rudimentary and the epithelium was cuboidal or mixed. Goblet cells were present in only one case and severe degenerative changes with large necrotic areas (about one-fourth of the cultured tissue) were observed in all the cultures (Table 1 and Fig. 4 d). No effect was observed when phosphate buffering salts and sodium chloride were added to the culture medium at the amounts usually present with $0.1 \mathrm{mg}$ peptides of fraction 9 . The toxic effect of fraction 9 was still clearly evident when an amount as small as $10 \mu$ g peptides was added per ml of culture medium. Moreover, in contrast to what previously observed with several types of cultured cells (13, 17), the toxic action of fraction 9 on the in vitro developing rat fetal intestine was not prevented by the addition of $1 \%$ fetal calf serum to the culture medium. Interestingly enough, fraction 9 at a concentration of $0.1 \mathrm{mg} / \mathrm{ml}$ did not affect in vitro cultured jejunal segments from 21-day-old rat fetuses.

\section{EFFECT OF WHEAT GLIADIN AND ALBUMIN FRACTIONS}

Undigested A-gliadin and $\alpha_{10}$-gliadin were tested at the concentration of 0.5 and $0.1 \mathrm{mg} / \mathrm{ml}$, respectively. Only the $\alpha_{10}$-gliadin exibited a toxic effect on in vitro developing rat fetal intestine
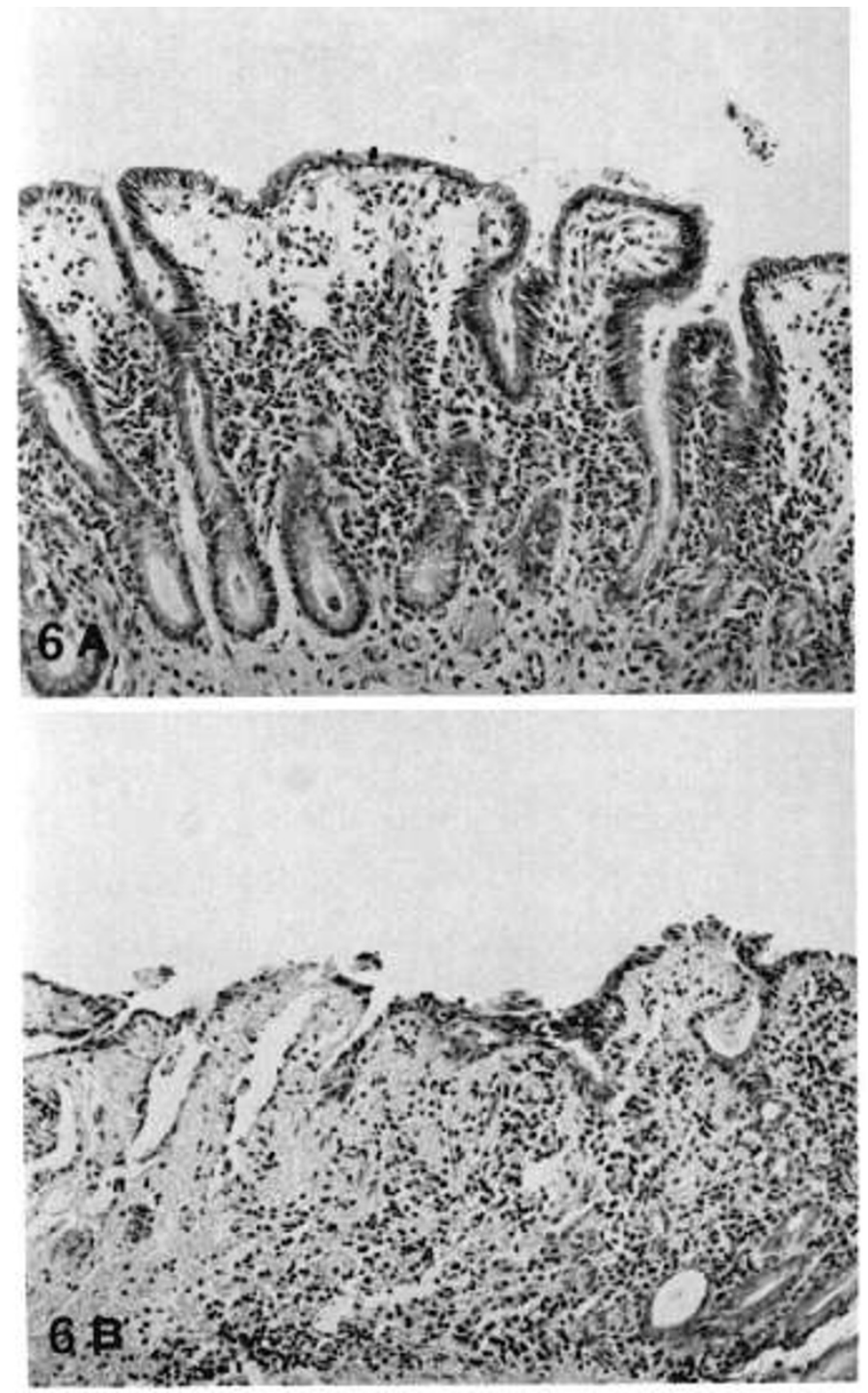

Fig. 6. Effect of peptic-tryptic-cotazym digest of wheat gliadin on in vitro cultured jejunal biopsy from a child with untreated celiac disease. $A$ no PTC-gliadin digest; $B$ with PTC-gliadin digest $(0.5 \mathrm{mg} / \mathrm{ml})$. Extensive degenerative changes are evident in the tissue treated with the PTC-gliadin digest. Hematoxylin-Eosin $(\times 150)$.

cultured for $48 \mathrm{hr}$. Morphologic alterations induced by the $\alpha_{10^{-}}$ gliadin were very similar to those induced by PTC gliadin digest and its fraction 9. Wheat albumin inhibitors of $\alpha$-amylase with molecular weights $60,000,24,000$ and 12,000 , purified according to Petrucci et al. (33), did not show any toxic activity for rat fetal intestine when tested at the concentration as high as $0.5 \mathrm{mg} / \mathrm{ml}$, without any previous digestion.

\section{DISCUSSION}

Among wheat albumin and gliadin fractions tested, only $\alpha_{10^{-}}$ gliadin showed inhibitory activity of in vitro development and morphogenesis of jejunum from 17- and 18-day-old rat fetuses. A similar activity was also displayed by PTC gliadin digest and its fraction 9 . These peptides were harmless for the jejunum from 21 day-old fetuses thus showing that the toxic effect is only expressed during early phase of mucosal differentiation and maturation. Such a toxic effect was not prevented by the addition of calf serum to the incubation medium and was not observed with PTC-digest from bovine serum albumin used as a control protein.

The transient character of such an effect is highly suggestive of an age-dependent protective mechanism of the rat intestine against wheat toxic peptides, associated with the maturation of intestinal mucosa; it may consist of development of a peculiar proteolytic 
activity other than peptic, tryptic, and cotazyme ones, secretion into the intestinal lumen of compounds capable of taking away toxic compounds, or disappearence during tissue development of a specific sensitive cell receptor site $(30,32,34)$. All these three mechanisms are compatible with present knowledges on fetal intestine maturation and further investigations with the organ culture system used in this work should provide better understanding of the involved mechanism.

As the enzymatic hydrolysis used for preparing gliadin peptides mimics the digestive process that occurs in the human intestinal lumen, similar peptides are likely to be formed in the duodenal lumen during in vivo digestion of gliadin. Then the effects observed on developing rat jejunum might be suggestive of some adverse effects induced by wheat proteins in man under the particular circumstances where intestinal mucosa is not fully developed or it regresses towards immature steps of development. It is suggested that under such circumstances (i.e., during early extrauterine life or in case of disease with intestinal mucosal atrophy) detoxifying mechanisms for wheat gliadin peptides might be impaired and wheat ingestion might cause intestinal troubles, as in secondary intolerance to wheat proteins and in celiac disease. Such an hypothesis is supported by the fact that PTC gliadin digest and fraction 9 that are toxic for the in vitro developing rat fetal jejunum also induce necrosis of in vitro cultured small intestinal mucosa from patients with active celiac disease (see data in Fig. 6 and data reported by Townley et al. (38).

The significance of in vitro organogenesis of fetal rat intestine as a model for identifying wheat components responsible for the pathogenesis of celiac disease is not entirely clear. In fact, this in vitro system is sensitive to PTC gliadin digest and fraction 9, which are considered to be toxic factors in celiac disease, as well as to undigested $\alpha_{10}$-gliadin, but it seems not affected by undigested Agliadin, that also has been reported to be a toxic factor in the pathogenesis of celiac disease. This point, however, deserves further investigations to be carried out with predigested A-gliadin. In fact, it is well known that gliadins are rather difficult to solubilize in salt solutions at a near neutral $\mathrm{pH}$. Thus, although at an accurate visual inspection A-gliadin and $\alpha_{10}$-gliadin appeared well solubilized in the tissue incubation medium, the possibility that the lack of effect of A-gliadin may depend on a solubility problem cannot be ruled out. Furthermore, the damaging effect of gliadin peptides on in vitro cultured small intestinal mucosa from patients with active celiac disease is probably mediated through immune mechanisms (26), whereas this is probably not the mechanism by which gliadin peptides damage the in vitro developing fetal rat small intestine. Finally, as fraction 9 as well as PTC-digest are heterogeneous peptidic fractions, further investigations are needed to establish whether the peptide(s) of fraction 9 able to damage in vitro cultured celiac mucosa and in vitro developing fetal rat small intestine are the same or not.

\section{REFERENCES AND NOTES}

1. Andrews, P.: Estimation of the molecular weights of proteins by Sephadex gel filtration. Biochem. J. 91: 222 (1964).

2. Bayless, T. M., and Swanson, V. L.: Comparison of Tropical sprue and adult coeliac disease (non tropical sprue). Gastroenterology, 46: 731 (1964).

3. Bernardin, J. E., Kasarda, D. D., and Mecham, D. R.: Preparation and characterization of $\alpha$-gliadin. J. Biol. Chem., 242: 445 (1967).

4. Bronstein, H. D., Haeffner, L. J., and Kowlessar, O. D.: Enzymatic digestion of gliadin: the effect of the resultant peptides in adult celiac disease. Clin. Chim. Acta. 14: 141 (1966).

5. Browning, T. H., and Trier, J. S.: Organ culture of mucosal biopsies of human small intestine. J. Clin. Invest., 48: 1423 (1969).

6. Buonocore, V., Petrucci, T., and Silano, V.: Wheat protein inhibitors of $\alpha$ Amylase. Phytochemistry, 16: 811 (1977).

7. Cooper, B. T., Holmes, G. K. T., Ferguson, R., Thompson, R. A.. and Cooke, W. $T$.: Gluten sensitive diarrhea without evidence of coeliac disease. Third International coeliac Symposium, Sepiember 18-21, 1977, Galway, Ireland.

8. Cornell, H. J., and Townley, R. R. W.: Investigation of possible intestinal peptidase deficiency in coeliac disease. Clin. Chim. Acta. 43: 113 (1973).

9. De Ritis, G., Falchuk, Z. M., and Trier, J. S.: Differentiation and maturation of cultured fetal rat jejunum. Developmental Biology, 45: 304 (1975).
10. Falchuk, Z. M., Gebhard, R. L.. Sessoms, C., and Strober, W.: An in vitro model of gluten-sensitive enteropathy. Effect of gliadin on intestinal epithelial cells of patients with gluten sensitive enteropathy in organ culture. J. Clin. Invest.. 53: 487 (1974).

11. Falchuk, Z. M., Gebhard, R. L., and Strober, W.: The pathogenesis of gluten sensitive enteropathy (celiac sprue): organ culture studies. In: W. T. J. M. Hekkens and A. S. Pena: Celiac Disease, p. 107 (Stenfert Kroese, Leiden. 1974).

12. Falchuk, Z. M., Sessoms, C., and Strober, W.: An in vitro model of glutensensitive enteropathy: evidence that gluten is not directly toxic to gastrointestinal epithelium. J. Clin. Invest., 51: 28a (1972).

13. Freed, D. L. J. and Cooper, R. J.: Cytoxicity of bread and soya protein in tissue culture. Lancet, 1: 371 (1977)

14. Hedberg, C. A., Melnyk, C. S. and Johnson, C. F.: Gluten enteropathy appearing after gastric surgery. Gastroenterology, 50: 796 (1966).

15. Hekkens, W. T. J. M., Haex, A. J. C.. and Willighagen, R. G. J.: Some aspects of gliadin fractionation and testing by a histochemical method. In: C. C. Booth and R. H. Dowling: Coeliac Disease, p. 11 (Churchill Livingstone, Edinburgh. 1970).

16. Hekkens, W. T. J. M., Van Den Aarsen, C. J., Gilliams, J. P. Lems-Van Kan, P. and Bouma-Frölich, G.: $\alpha$-Gliadin structure and degradation. In: W. Th. J. M. Hekkens and A. S. Pena. Coeliac Disease, p. 39 (Stenfert Kroese, Leiden. 1974)

17. Hudson, D. A., Cornell, H. J., Purdham, D. R.. and Rolles, C. J.: No specific cytotoxicity of wheat gliadin components towards cultured human cells. Lancet. 1: 339 (1976).

18. Huebner, F. R., and Rothfus, J. A.: Gliadin proteins from different varieties of wheats. Cereal Chem., 45: 242 (1968).

19. Jones, R. W., Babcock. G. E., Taylor, N. W., and Senti, F. R.: Molecular weights of wheat gluten fractions. Arch. Biochem. Biophys., 94: 483 (1961).

20. Jones, R. W.. Taylor, N. W., and Senti, F. R.: Electrophoresis and fractionation of wheat gluten. Arch. Biochem. Biophys., 84: 363 (1959).

21. Jos, J., Charbonnier, L., Mougenot, J. F., Mosse, J., and Rey, J.: Isolation and characterization of the toxic fraction of wheat gliadin in coeliac disease. Third International Coeliac Symposium, September 18-21, 1977. Galway, Ireland.

22. Jos, J., Lenois, G., De Ritis, G., and Rey. J.: In vitro culturing of biopsies from children. In: W. T. J. M. Hekkens and A. S. Pena: Celiac Disease, p. 9| (Stenfert Kroese, Leiden, 1974).

23. Jos, J., Lenoir, G., De Ritis, G., and Rey, J.: In vitro pathogenetic studies of coeliac disease. Effects of protein digests on coeliac intestinal biopsy specimens maintained in culture for 48 hours. Scand. J. Gastroent., 10: 121 (1975).

24. Kasarda, D. D.: Celiac Disease: malabsorption of nutrients induced by a toxic factor in gluten. In: M. Friedman: Protein nutritional quality of foods and feeds, p. 565 (Dekker. New York, 1975)

25. Kasarda, D. D., Qalset. C. O., Mecham, D. K., Goodenberger, D. M., and Strober, W.: A test of toxicity of bread made from wheat lacking alpha gliadins coded for by the $6 \mathrm{~A}$ chromosome. Third International Coeliac Symposium, September 18-21, 1977. Galway, Ireland.

26. Katz, A. J., Falchuk, Z. M., Strober, W., and Shwachman. H.: Gluten-sensitive enteropathy. Inhibition by cortisol of the effect of gluten protein in vitro. $\mathrm{N}$ Engl. J. Med., 295: 131 (1976)

27. Kendall, M. J., Schneider, R., Cox, P. S., and Hawkins, C. F.: Gluten subfractions in coeliac disease. Lancet, 2: 1065 (1972).

28. Levine, R. A., Briggs, G. W., Harding, R. S.. and Nolte, L. B.: Prolonged gluten administration in normal subjects. N. Engl. J. Med.. 274: 1109 (1966).

29. Luft, J. H.: Improvements in epoxy resin embedding methods. J. Biophys. Biochem. Cytol., 9: 409 (1961).

30. Mannino, R. J., and Burger, M. M.: Growth inhibition of animal cells by succinylated concanavalin A. Nature, 256: 19 (1975).

31. McNeish, A. S., Rolles, C. J., and Arthur. L. J. H.: Criteria for diagnosis of temporary gluten intolerance. Arch. Dis. Childhood, 51: 275 (1976).

32. Moran, D.: The action of concanavalin $A$ on migrating and differentiating neural crest cells. Exp. Cell. Res., 86: 365 (1974).

33. Petrucci, T., Tomasi, M., Cantagalli, P. and Silano, V.: Comparison of wheat albumin inhibitors of $\alpha$-amylase and trypsin. Phytochemistry, 13: 2487 (1974).

34. Pienkowski, M.: Study of the growth regulation of preimplantation mouse embryos using concanavalin A. Proc. Soc. Exp. Biol. Med., 145: 464 (1974).

35. Richardson, K. C., Jarett, L., and Finke, E. H.: Embedding in epoxy resin for ultrathin sectioning in electron microscopy. Stain Technol., 35: 313 (1960).

36. Rudman, D.. Yalambos, J. T.. Wenger. J., and Achord. J.: Adverse effects of dietary gluten in four patients with regional enteritis. Am. J. Clin. Nutr., 24: 1068 (1971).

37. Spackmann, D. M.. Stein, W. H., and Moore, S.: Automatic recording apparatus for use in the chromatography of amino acids. Analyt. Chem., 30: 1190 (1958).

38. Townley, R. R. W., Bhathal, P. S., Cornell, H. J., and Mitchell, J. D.: Toxicity of wheat gliadin fractions in celiac disease. Lancet, $1: 1363$ (1973).

39. The authors thank Dr. F. R. Huebner for generously supplying the $\alpha$-gliadin fraction and Dr. D. D. Kasarda for the A-gliadin sample.

40. Preliminary data were presented at the 10th Annual Meeting of the European Society for Paediatric Gastroenterology, Utrecht, May 1314, 1977.

41. Requests for reprints should be addressed to: Salvatore Auricchio, Clinica Pediatrica, II Facolta di Medicina e Chirurgia. Via Sergio Pansini, 5-80131, Naples, Italy.

42. Received for publication October 10, 1978

43. Accepted for publication May 10, 1979. 